\title{
Maize (Zea mays L.) Growth and Yield Response to Tillage Methods and Fertilizer Combinations in the Midland Agro-ecological Zones of Kenya
}

\author{
Hillary M. O. Otieno ${ }^{1,2, a,{ }^{*} \text {, Shamie Zingore }}{ }^{3, b}$, George N. Chemining'wa ${ }^{1, c}$, Charles K. Gachene ${ }^{4, d}$ \\ ${ }^{1}$ Department of Plant Science and Crop Protection, University of Nairobi, Nairobi, Kenya \\ ${ }^{2}$ Department of Agricultural Research, One Acre Fund, Nairobi, Kenya \\ ${ }^{3}$ International Plant Nutrition Institute, Sub-Saharan Africa Program, Nairobi, Kenya \\ ${ }^{4}$ Department of Land Resource Management and Agricultural Technology, University of Nairobi, Nairobi, Kenya \\ * Corresponding author
}

\begin{tabular}{|c|c|}
\hline A R T I C L E I N F O & A B S T R A C T \\
\hline $\begin{array}{l}\text { Keywords: } \\
\text { Conservation agriculture } \\
\text { Crop residue management } \\
\text { Fertilizer application } \\
\text { Maize yield } \\
\text { Zero tillage. }\end{array}$ & 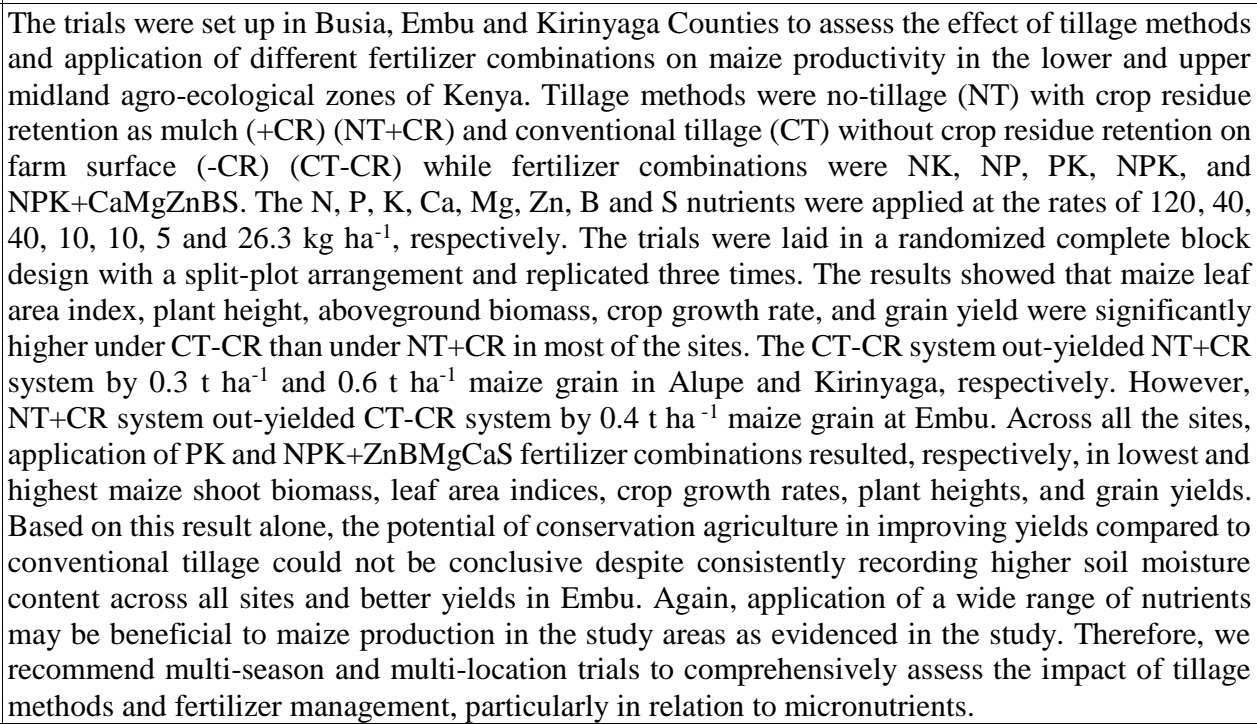 \\
\hline
\end{tabular}

\section{Introduction}

Maize (Zea mays L.) is an important crop grown in Kenya by almost all households for food, income generation, source of livestock feed, and fuel for poor homes (Otieno et al., 2019). Despite the benefits, the average nationwide productivity of maize has remained below $2 \mathrm{t} \mathrm{ha}^{-1}$ mainly due to water stress and soil infertility (Okalebo et al., 2007; Otieno, 2019a; Otieno et al., 2018b). Low and erratic rainfall due to climate change has become the greatest challenge in maize production in the country. The frequency of drought spells has been high over the past decades resulting in poor and sometimes total maize failure leading to chronic hunger and deaths across the country (Omoyo et al., 2015; Reliefweb Report, 2019). The situation has worsened further due to lack of feasible and cost-effective strategies of conserving this limited resource. An attempt to carry out irrigation has failed due to high poverty levels among farming families (Otieno et al., 2019). Soil infertility is another important constraint hindering maize productivity across the country. High nutrient depletion levels have been reported in central, eastern and western parts of Kenya (Sanchez et al., 1997; Okalebo et al., 2007; Otieno et al., 2018a; 2018b; 2019) due to continuous cultivation without adequate external nutrient replenishment (Mwangi et al., 1998). The small quantities of applied nutrients are also lost through poor maize agronomic practices such as poor weed control (characterized by late timing and poor weeding) and soil erosion. The losses through plant extraction can also not be 
ignored as most of the nutrients are lost through poor residue management. As reported by Drechsel et al. (2001), about 70, 90 and $100 \%$ of all N, K and P nutrient losses, respectively, are due to erosion and plant extraction. The situation is aggravated further by the use of obsolete fertilizer recommendations that do not take care of the current low nutrient status across the country (Mugwe et al., 2009; Vanlauwe et al., 2010). As conventionally practiced, crop residues are exported from the fields for other functions (e.g. animal feed, thatching materials, and fuel), resulting in soil nutrient mining and bare soils that promote high rates of erosion and runoff. This practice reduces nutrient recycling leading to net negative nutrient balances. In addition, fertilizers applied for maize production are majorly NP-based sources with no attention given to other essential nutrients like $\mathrm{Mg}, \mathrm{Ca}, \mathrm{Zn}, \mathrm{B}$ and $\mathrm{S}$. This is despite several researchers demonstrating their important contributions in crop production, for example Zinc (Yerokun and Chirwa, 2014), sulphur and magnesium (Szulc et al., 2008), calcium (Fageria et al., 2010) and boron (Kanwal et al., 2008). There is therefore a need to assess and adopt an eco-friendly system that conserves soil moisture and nutrients for better maize production. Adoption of no-tillage and proper crop residue management through total retention as mulch has been reported to not only reduce the cost of production but also conserve soil water and improve soil nutrient recycling and general soil health (Otieno et al., 2019). Therefore, this study aimed at assessing the influence of tillage methods and fertilizer combinations on maize performance across three midland agro-ecological zones in Kenya.

\section{Materials and Methods}

\section{Description of The Study Site}

The trials were carried out at Kenya Agricultural and Livestock Research Organization (KALRO)- Alupe in Busia County (located on $34^{\circ} 07^{\prime} 28.6^{\prime \prime} \mathrm{E}$ and $00^{\circ} 30^{\prime} 10.1^{\prime \prime} \mathrm{N}$ ), KALRO- Embu in Embu County (located on $37^{\circ} 19^{\prime}$ 10.4' $\mathrm{E}$ and latitude $00^{\circ} 33^{\prime} 29.4$ ' $\mathrm{S}$ ), and Kirinyaga Technical Institute (KTI) in Kirinyaga County (located on $37^{\circ} 19^{\prime} 10.4^{\prime \prime} \mathrm{E}$ and latitude $00^{\circ} 30^{\prime} 18.3^{\prime}$ ' S). These sites cover agriculturally important lower (Alupe) and upper (Embu and Kirinyaga) midland agro-ecological zones with a bi-modal rainfall pattern, experiencing wet seasons from March to May (long rains season) and September to December (short rains season) with an annual rainfall range of $930 \mathrm{~mm}$ to $1550 \mathrm{~mm}$. The daily mean temperature is about $24^{\circ} \mathrm{C}$ in Alupe, $18^{\circ} \mathrm{C}$ in Embu and $23^{\circ} \mathrm{C}$ in Kirinyaga. The soils are predominantly Ferralsols with sandy-clay texture in Alupe and Nitisols with clay-loam texture in Embu and Kirinyaga (Jaetzold and Schmidt, 1983). All the soils are deep with good water holding capacity (Jaetzold and Schmidt, 1983). The site-specific soil fertility characteristics of the study sites are shown in Table 1.

\section{Experimental Design and Treatments}

The experiment was laid out in a randomized complete block design with a split-plot arrangement and replicated three times. The experiment comprised 30 plots, each measuring $8 \mathrm{~m} \times 10 \mathrm{~m}$. A space of $1.5 \mathrm{~m}$ and $1 \mathrm{~m}$ was left between blocks and plots, respectively. Between the blocks, a trench of $1 \mathrm{~m}$ wide and $1 \mathrm{~m}$ deep was dug to reduce chances of nutrients flowing from one plot to the other- avoiding nutrient contamination. Two tillage systems and five fertilizer combinations were evaluated. The tillage systems were no-tillage (NT) with crop residue retention as mulch $(+\mathrm{CR})(\mathrm{NT}+\mathrm{CR})$ and conventional tillage (CT) with no crop residue retention (-CR) (CT-CR)this is the usual practice applied by farmers in the regions, they remove or burn crops residues after harvesting. The percentage of soil covered by the maize crop residue (as mulch) was above $75 \%$ on all no-till plots at the time of planting in all the sites. The soil surface cover by crop residues was determined visually. This cover was more than the minimum required under conservation. There was no importation of crop residue from neighboring plots- all residues were obtained within the same plot from the maize crop grown to deplete nutrients during 2013 short rains season. The fertilizer combinations were NK, NP, PK, $\mathrm{NPK}$, and NPK+CaMgZnBS. Nitrogen (N), phosphorus $(\mathrm{P})$, potassium $(\mathrm{K})$, calcium $(\mathrm{Ca})$, magnesium $(\mathrm{Mg})$, zinc $(\mathrm{Zn})$, boron (B) and sulphur (S) nutrients were applied at rates of $120,40,40,10,10,5$ and $26.3 \mathrm{~kg} / \mathrm{ha}$, respectively, using urea, triple superphosphate (TSP), muriate of potash (MOP), calcium sulphate, magnesium sulphate, zinc sulphate and borax nutrients, respectively. Nitrogen was applied in three equal splits (at planting, V4 and V10 stages of maize vegetative growth) while the rest of the nutrients were applied basally at planting. The tillage systems were assigned to the main plots and fertilizer combinations assigned to the subplots. Maize variety, DK 8031, was selected and used for the trials in all sites due to its popularity in the region and adaptability to the prevailing climatic conditions.

Table 1. The baseline soil chemical characteristics of the study sites

\begin{tabular}{l|ccc}
\hline \multicolumn{1}{c|}{ Parameter } & Alupe & Embu & Kirinyaga \\
\hline $\mathrm{pH}$ (water) & 4.75 & 4.44 & 5.95 \\
Total soil organic carbon (\%) & 1.29 & 2.00 & 2.56 \\
Total nitrogen (\%) & 0.14 & 0.21 & 0.28 \\
Extractable potassium (me \%) & 1.04 & 0.28 & 6.14 \\
Phosphorus (ppm) & 26.20 & 37.80 & 44.90 \\
Calcium (me \%) & 0.32 & 1.60 & 1.70 \\
Magnesium (me \%) & 3.28 & 5.20 & 7.46 \\
Zinc (ppm) & 4.30 & 18.80 & 10.30 \\
\hline
\end{tabular}

\section{Agronomic Practices}

During the 2013/2014 short rains season, DK 8031 maize variety was planted to deplete nutrients and to provide crop residue to be used as mulch with no-till in conservation agriculture plots during 2014 long rains season. Other subsequent practices were carried out as explained by Otieno et al. (2019): land preparation on CT$\mathrm{CR}$ plots was done a week before the onset of the rains, during which tilling was done using locally available handhoes. Planting of maize was done at $75 \mathrm{~cm}$ by $25 \mathrm{~cm}$ spacing using a calibrated planting string and plant population maintained to the level of at least 53,000 plants per hectare. At planting, correct quantities of fertilizers were placed in planting holes then mixed with soil before seed placement to avoid direct contact that could otherwise cause germination failure. Nitrogen, as urea fertilizer, was applied in three equal splits (at planting, V4 and V10 stages 
of maize vegetative growth) while the rest of the nutrients were applied at planting. The V4 and V10 are vegetative (V) growth phases of maize when the crop has 4 and 10 visible leaf collars, respectively (Ciganda et al., 2009). Two maize seeds were planted per hole and later thinned to one plant per hill after emergence. At two days after planting, the NT+CR plots were sprayed with a mixture of Dual Gold 960 EC and Weedal 480 SL herbicide products at a rate of $1.51 \mathrm{ha}^{-1}$ each to kill already existing weeds then residues returned back. To ensure safety of the applicator, full personal protective equipment was used and best practices followed as described by Otieno (2019b). The first and second weeding on conventional tillage plots and topdressing on all plots were done at V4 and V10 stages of maize growth. Weed populations on NT+CR plots were monitored and contained below economic injury level using D-Amine 72\% (2, 4-Dichlorophenylacetic acid 600 $\left.\mathrm{g}^{-1}\right)$. Pests and diseases were monitored regularly and remedial action taken as required: Bulldock at the rate of 6 $\mathrm{kg} \mathrm{ha}^{-1}$ was applied to maize crops approximately 30 days after crop emergence by putting a pinch in the third leaf funnel of every crop to control stalk borers. Squirrels were also controlled through scaring from the time of planting to 10 days after emergence. At maturity stage (about four months after emergence), maize was harvested manually.

\section{Data Collection}

Data collected were biomass at 30,60, 90, and 120 days after emergence (DAE), leaf length and width, plant height, grain moisture at harvesting and total stover weight.

Soil moisture retention was assessed at 30,60, and 90 DAE in Embu and Kirinyaga. The data from Alupe site could not be reported here to due contamination during processing in the laboratory. Five soil samples were randomly taken within at $0-30 \mathrm{~cm}$ depth from each replicate and their weights taken right at the field. The samples were then dried at $105^{\circ} \mathrm{C}$ to a constant weight in the laboratory. The differences between the fresh and dry weights of the samples were averaged and used to calculate the soil water retention according to Klute (1986).

Shoot biomass assessment was done at 30, 60, 90, and 120 (at harvesting) DAE- the assessment at the first three stages involved 10 randomly selected maize plants while at 120 DAE the assessment was done based on the harvest from the $15 \mathrm{~m}^{2}$ net plot. Fresh weights of plants sampled were taken and a subsample of $500 \mathrm{~g}$ containing chopped leaves and stems oven-dried at $65^{\circ} \mathrm{C}$ to a constant weight for use in dry matter determination. Shoot biomass was used to compute crop growth rates. Crop growth rate (CGR) is the rate of dry matter production per unit area. The crop growth rate was calculated based on two successive harvests using Hunt (2003) equation.

At physiological maturity, plant heights were measured using a meter ruler and recorded in centimetres. During this activity, five plants were randomly picked within the same plot and their heights measured from the base of the plant to the tip of the plant and then averaged. Leaf length (L) and width (W) were measured using a ruler from the tip to the base and at the widest part, respectively, at physiological maturity. These measurements were then used for calculating leaf area (LA) using the formula described by Blanco and Folegatti (2003) equation. Leaf area index (LAI) was then computed as described by Pierce and Running (1988). At harvest, plant count, number of cobs, fresh weights of stover, cobs and grain moisture content were collected within a net plot measuring $3.75 \mathrm{~m}$ by $4 \mathrm{~m}\left(15 \mathrm{~m}^{2}\right)$. The number of plants and cobs per net plot were counted manually and recorded. Harvesting was done when the average grain moisture content was $20 \%$. Grain yield $\left(\mathrm{t} \mathrm{ha}^{-1}\right)$ per ha was computed from the net plot and adjusted to $14 \%$ moisture content.

\section{Statistical Analysis}

Collected data were subjected to analysis of variance (ANOVA) using Genstat statistics computer software, 15th version. Where $\mathrm{F}$ tests were significant, means were compared using Fisher's protected least significance difference (L.S.D.) procedure at $\mathrm{P} \leq 0.05$.

\section{Results}

There was generally low rainfall during the production period (week 1-15) (Figure 1). Planting and plant emergence occurred when soil moisture levels were low (weeks 1 and 2). Then rainfall increased in all sites after 5 and 6 weeks after emergence before decreasing. The rainfall then remained low during the active vegetative phases (weeks 8-9) for all sites. From VT (8 weeks after planting) stage, there was a reduction in rainfall through to R1-R3 (weeks 10 to 13 after planting) in Alupe and Kirinyaga sites. However, Embu site experienced an increase in rainfall at week 11 . Grain filling and maturation of maize crops occurred during low rainfall periods (week 11 to 15 ) (Figure 1).

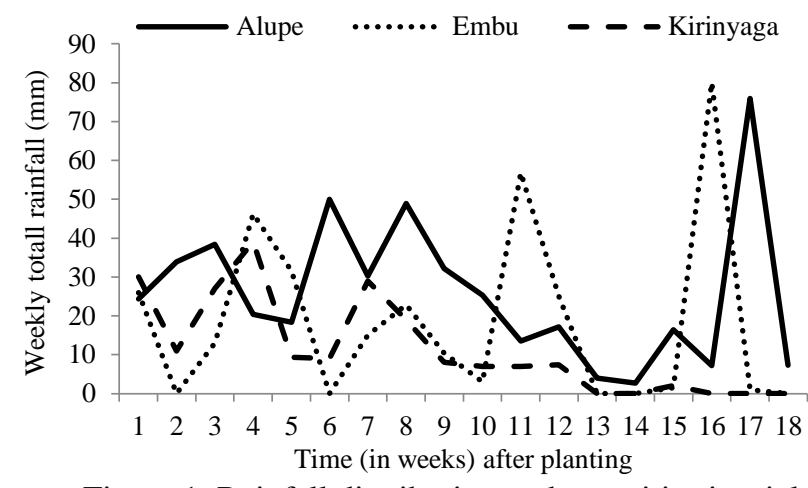

Figure 1. Rainfall distribution and quantities in trial locations during 2014 long rain season

\section{Effect of Tillage Method and Fertilizer Application on Maize Leaf Area Index and Height}

The tillage method had a significant $(\mathrm{P}<0.001)$ effect on maize leaf area index (LAI) at Kirinyaga and Embu sites (Table 2). Higher maize LAIs were recorded under conventional tillage (CT) with no crop residue retention (-CR) (CT-CR) than under no-till (NT) with crop residue retention as mulch $(+\mathrm{CR})(\mathrm{NT}+\mathrm{CR})$ at Embu and Kirinyaga trial sites. The LAI ranged between 3.1 and 4.9 under NT+CR and 3.2 and 5.5 under CT-CR tillage system.

Fertilizer application also affected LAI in Alupe $(\mathrm{P}=0.01)$, Embu $(\mathrm{P}=0.01)$ and Kirinyaga $(\mathrm{P}<0.001)$ sites. The NPK+ZnBMgCaS had higher LAI than NK, NP and PK treatments in both sites and NPK in Embu. No significant differences in LAIs were observed among NK, NP and PK treatments in all the sites. The NPK treatment 
had higher LAI than NK, NP and PK treatments at Kirinyaga and PK treatment in Alupe trial site. In Alupe and Embu sites, NK, NP, and NPK treatments were similar.

In terms of plant height, only fertilizer combinations recorded significant effects; $\mathrm{P}<0.001$ in Alupe, $\mathrm{P}=0.01$ in Embu and $\mathrm{P}=0.01$ in Kirinyaga (Table 2). The $\mathrm{PK}$ fertilizer combination recorded shorter plants than NPK and $\mathrm{NPK}+\mathrm{ZnBMgCaS}$ plots in all the sites. The PK and NK fertilizer combinations recorded similar plant heights at Alupe and Kirinyaga sites but NK had taller plants than PK in Embu. In all the sites, there were no significant differences between NP and NPK treatments and between $\mathrm{NPK}$ and $\mathrm{NPK}+\mathrm{ZnBMgCaS}$ treatments in maize plant height. Generally, taller maize plants were recorded in $\mathrm{NPK}+\mathrm{ZnBMgCaS}$ plots than NK, NP and PK plots across all trial sites. The average plant heights varied from $221 \mathrm{~cm}$ at Alupe to $269 \mathrm{~cm}$ at Kirinyaga. A non-significant interaction between tillage method and fertilizer combination was observed for maize LAI and height at all the sites (Table 2).

Table 2. Effect of tillage method and fertilizer application on maize leaf area index and height at Alupe, Embu and Kirinyaga trial sites during 2014 long rains season

\begin{tabular}{|c|c|c|c|c|c|c|}
\hline \multirow{2}{*}{ Treatment } & \multicolumn{3}{|c|}{ Leaf area index (LAI) } & \multicolumn{3}{|c|}{ Maize height $(\mathrm{cm})$} \\
\hline & Alupe & Embu & Kirinyaga & Alupe & Embu & Kirinyaga \\
\hline \multicolumn{7}{|c|}{ Tillage method (TM) } \\
\hline $\mathrm{NT}+\mathrm{CR}$ & 3.10 & 4.30 & 4.90 & 219 & 228 & 265 \\
\hline CT-CR & 3.20 & 4.90 & 5.50 & 222 & 225 & 273 \\
\hline$P$ value & 0.098 & $<0.001$ & $<0.001$ & 0.131 & 0.072 & 0.083 \\
\hline $\mathrm{LSD}_{0.05}$ & ns & 0.21 & 0.25 & ns & ns & ns \\
\hline \multicolumn{7}{|c|}{ Fertilizer combination (FC) } \\
\hline NK & 3.00 & 4.50 & 4.90 & 206 & 224 & 263 \\
\hline NP & 3.00 & 4.50 & 4.90 & 213 & 228 & 270 \\
\hline PK & 2.60 & 4.40 & 4.80 & 200 & 218 & 262 \\
\hline NPK & 3.50 & 4.70 & 5.50 & 235 & 230 & 274 \\
\hline $\mathrm{NPK}+\mathrm{ZnBMgCaS}$ & 3.80 & 5.00 & 5.70 & 248 & 233 & 276 \\
\hline $\mathrm{P}$ value & 0.010 & 0.01 & $<0.001$ & $<0.001$ & 0.01 & 0.01 \\
\hline $\mathrm{LSD}_{0.05}$ & 0.60 & 0.30 & 0.40 & 22 & 5 & 7 \\
\hline \multicolumn{7}{|c|}{ TM x FC interaction } \\
\hline $\mathrm{P}$ value & 0.713 & 0.592 & 0.147 & 0.412 & 0.093 & 0.096 \\
\hline $\mathrm{LSD}_{0.05}$ & ns & ns & ns & ns & ns & ns \\
\hline
\end{tabular}

$\mathrm{NT}=$ no-tillage, $\mathrm{CT}=$ conventional tillage, $+\mathrm{CR}=$ retention of crop residue, $-\mathrm{CR}=$ removal of crop residues, $\mathrm{NT}+\mathrm{CR}=$ no-till with crop residue retention, $\mathrm{CT}-\mathrm{CR}=$ conventional tillage with no crop residue retention, ns= not significant.

\section{Effect of Tillage Method and Fertilizer Combination on Maize Crop Growth Rate}

The maize crop growth rate (CGR) was high under CTCR compared to under NT+CR tillage method across all growth periods considered except at 30 to 60 days after emergence (DAE) in Embu (Table 3). Low and high CGR values were recorded at planting to $30 \mathrm{DAE}$ and 60 to 90 DAE periods respectively (Table 3 ). Significant effect of tillage method on CGR was recorded at planting to $30 \mathrm{DAE}$ period in Embu $(\mathrm{P}=0.01)$ and Kirinyaga $(\mathrm{P}=0.01)$ and at 60 to 90 DAE period in Alupe $(\mathrm{P}=0.01)$ (Table 3). The CTCR system had significantly higher CGR $\left(0.95 \mathrm{~g} \mathrm{~m}^{-2} \mathrm{~d}^{-1}\right)$ than NT+CR $\left(0.67 \mathrm{~g} \mathrm{~m}^{-2} \mathrm{~d}^{-1}\right)$ from planting to $30 \mathrm{DAE}$ in Embu. Similarly, from 60 to 90 DAE, CT-CR system had significantly higher CGR (31.58 $\left.\mathrm{g} \mathrm{m}^{-2} \mathrm{~d}^{-1}\right)$ than NT+CR system $\left(26.93 \mathrm{~g} \mathrm{~m}^{-2} \mathrm{~d}^{-1}\right)$ in Alupe.

The effect of fertilizer combinations on CGR was significant $(\mathrm{P}=0.041$ to $\mathrm{P}<0.001)$ across all the growth periods and sites (Table 3). In general, PK and $\mathrm{NPK}+\mathrm{ZnBMgCaS}$ combinations recorded numerically low and high CGR across all periods and sites, respectively. At planting to $30 \mathrm{DAE}$, the $\mathrm{PK}$ combination recorded significantly lower CGR than NP, NPK and $\mathrm{NPK}+\mathrm{ZnBMgCaS}$ across all sites. At 30 to $60 \mathrm{DAE}$, the PK combination recorded significantly lower CGR than $\mathrm{NP}$ and NPK in Alupe, NP, NPK, and NPK+ZnBMgCaS in Embu, and NPK and NPK+ZnBMgCaS in Kirinyaga. At 60 to $90 \mathrm{DAE}$, the PK combination recorded significantly lower CGR than NPK and NPK+ZnBMgCaS in Alupe, all combinations in Embu, and NPK and NPK $+\mathrm{ZnBMgCaS}$ in Kirinyaga.

On the other, at planting to $30 \mathrm{DAE}, \mathrm{NPK}+\mathrm{ZnBMgCaS}$ combination recorded significantly higher CGR than all other treatments in Alupe, all treatments except NPK in Embu and Kirinyaga. At 30 to $60 \mathrm{DAE}, \mathrm{NPK}+\mathrm{ZnBMgCaS}$ treatment recorded higher CGR than all other treatments in Alupe, only PK treatment in Embu, and all other treatments except NPK in Kirinyaga. At 60 to 90 DAE, $\mathrm{NPK}+\mathrm{ZnBMgCaS}$ treatment had higher CGR than all treatments except NPK combination in Alupe and Embu, and only PK in Kirinyaga.

Application of fertilizer combinations influenced maize CGRs that ranged from $0.49 \mathrm{~g} \mathrm{~m}^{-2} \mathrm{~d}^{-1}$ (Embu site) to 40.56 $\mathrm{g} \mathrm{m}^{-2} \mathrm{~d}^{-1}$ (Alupe site) (Table 3 ). No significant interaction effect of tillage method and fertilizer application on CGR was observed during this trial.

\section{Effect of Tillage Method and Fertilizer Combinations} on Maize Aboveground Biomass

The effect of tillage method on aboveground biomass production was significant $(\mathrm{P}=0.01)$ in Embu and Kirinyaga at 30 days after emergence (DAE) only (Table 4). During this period, maize under CT-CR tillage system recorded higher biomass than maize under NT+CR tillage system. Across the periods considered for biomass assessment, CTCR tillage system consistently produced numerically high biomass yields compared to NT+CR tillage systems except at $60 \mathrm{DAE}$ in Embu site and $120 \mathrm{DAE}$ in all sites. 
Table 3. Maize crop growth rate $\left(\mathrm{g} \mathrm{m}^{-2} \mathrm{~d}^{-1}\right)$ as affected by tillage method and fertilizer combination at Alupe, Embu and Kirinyaga trial sites during 2014 long rains season

\begin{tabular}{|c|c|c|c|c|c|c|c|c|c|}
\hline \multirow{2}{*}{ Treatment } & \multicolumn{3}{|c|}{ Planting to $30 \mathrm{DAE}$} & \multicolumn{3}{|c|}{$30 \mathrm{DAE}$ to $60 \mathrm{DAE}$} & \multicolumn{3}{|c|}{$60 \mathrm{DAE}$ to $90 \mathrm{DAE}$} \\
\hline & Alupe & Embu & Kirinyaga & Alupe & Embu & Kirinyaga & Alupe & Embu & Kirinyaga \\
\hline \multicolumn{10}{|c|}{ Tillage method (TM) } \\
\hline $\mathrm{NT}+\mathrm{CR}$ & 1.86 & 0.67 & 1.05 & 13.13 & 21.15 & 23.61 & 26.93 & 31.96 & 23.93 \\
\hline CT-CR & 2.15 & 0.95 & 1.83 & 13.34 & 19.94 & 23.76 & 31.58 & 32.97 & 25.38 \\
\hline $\mathrm{P}$ value & 0.067 & 0.01 & 0.01 & 0.093 & 0.088 & 0.105 & 0.01 & 0.099 & 0.068 \\
\hline$\underline{\mathrm{LSD}_{0.05}}$ & ns & 0.17 & 0.34 & ns & ns & ns & 2.93 & ns & ns \\
\hline \multicolumn{10}{|c|}{ Fertilizer combination (FC) } \\
\hline NK & 1.76 & 0.56 & 1.30 & 12.55 & 19.92 & 22.53 & 20.25 & 32.52 & 23.02 \\
\hline NP & 2.05 & 0.90 & 1.49 & 12.88 & 21.04 & 23.63 & 26.57 & 32.54 & 24.63 \\
\hline PK & 1.45 & 0.49 & 1.14 & 11.64 & 18.02 & 22.41 & 19.60 & 30.20 & 21.64 \\
\hline NPK & 2.14 & 1.01 & 1.52 & 13.67 & 21.46 & 24.54 & 39.27 & 33.17 & 26.47 \\
\hline $\mathrm{NPK}+\mathrm{ZnBMgCaS}$ & 2.64 & 1.08 & 1.75 & 15.43 & 22.30 & 25.31 & 40.56 & 33.89 & 27.54 \\
\hline$P$ value & $<0.001$ & $<0.001$ & $<0.001$ & $<0.001$ & 0.022 & 0.01 & $<0.001$ & $<0.001$ & 0.041 \\
\hline$\underline{\mathrm{LSD}_{0.05}}$ & 0.44 & 0.14 & 0.30 & 1.57 & 2.63 & 1.33 & 11.60 & 1.32 & 5.38 \\
\hline \multicolumn{10}{|c|}{$\mathrm{TM} \times \mathrm{FC}$ interaction } \\
\hline $\mathrm{P}$ value & 0.071 & 0.091 & 0.101 & 0.240 & 0.174 & 0.332 & 0.099 & 0.491 & 0.187 \\
\hline $\mathrm{LSD}_{0.05}$ & ns & ns & ns & ns & ns & ns & ns & ns & ns \\
\hline
\end{tabular}

$\mathrm{DAE}=$ days after emergence, $\mathrm{NT}=$ no-tillage, $\mathrm{CT}=$ conventional tillage,$+\mathrm{CR}=$ retention of crop residue, $-\mathrm{CR}=$ removal of crop residues, $\mathrm{NT}+\mathrm{CR}=$ notill with crop residue retention, $\mathrm{CT}-\mathrm{CR}=$ conventional tillage with no crop residue retention, $\mathrm{LSD}=$ least significant difference, $\mathrm{ns}=$ not significant. Biomass at 120 DAE had no cobs.

Table 4. Effect of tillage method and fertilizer combination on aboveground biomass production (t/ha) at Alupe, Embu and Kirinyaga trial sites during 2014 long rains season

\begin{tabular}{|c|c|c|c|c|c|c|c|c|c|c|c|c|}
\hline \multirow{2}{*}{ Treatment } & \multicolumn{3}{|c|}{$30 \mathrm{DAE}$} & \multicolumn{3}{|c|}{$60 \mathrm{DAE}$} & \multicolumn{3}{|c|}{$90 \mathrm{DAE}$} & \multicolumn{3}{|c|}{$120 \mathrm{DAE}$} \\
\hline & Alupe & Embu & Kirinyaga & Alupe & Embu & irinyaga & Alupe & Embu & Kirinyaga & Alupe & Embu & Kirinyaga \\
\hline \multicolumn{13}{|c|}{ Tillage method (TM) } \\
\hline $\mathrm{NT}+\mathrm{CR}$ & 0.52 & 0.20 & 0.31 & 4.50 & 6.55 & 7.75 & 12.78 & 16.00 & 14.56 & 3.53 & 5.81 & 7.54 \\
\hline CT-CR & 0.64 & 0.29 & 0.55 & 4.51 & 6.27 & 8.00 & 13.84 & 16.33 & 15.41 & 3.43 & 5.30 & 7.40 \\
\hline$P$ value & 0.191 & 0.01 & 0.01 & 0.067 & 0.291 & 0.070 & 0.085 & 0.810 & 0.729 & 0.891 & 0.581 & 0.648 \\
\hline $\mathrm{LSD}_{0.05}$ & ns & 0.05 & 0.10 & ns & ns & ns & ns & ns & ns & ns & ns & ns \\
\hline \multicolumn{13}{|c|}{ Fertilizer combination (FC) } \\
\hline$\overline{\mathrm{NK}}$ & 0.51 & 0.17 & 0.39 & 4.02 & 6.14 & 7.31 & 11.13 & 16.04 & 14.21 & 2.42 & 5.45 & 7.35 \\
\hline NP & 0.59 & 0.27 & 0.45 & 4.61 & 6.46 & 7.53 & 11.82 & 16.45 & 14.70 & 3.59 & 5.64 & 7.54 \\
\hline PK & 0.45 & 0.15 & 0.34 & 4.00 & 5.68 & 7.31 & 10.07 & 15.27 & 14.02 & 2.40 & 4.77 & 6.78 \\
\hline NPK & 0.61 & 0.30 & 0.46 & 4.70 & 6.74 & 7.81 & 16.11 & 16.50 & 15.98 & 3.68 & 5.82 & 7.63 \\
\hline $\mathrm{NPK}+\mathrm{ZnBMgCaS}$ & 0.72 & 0.33 & 0.53 & 5.20 & 7.01 & 8.07 & 17.41 & 16.61 & 16.02 & 4.84 & 6.07 & 8.05 \\
\hline $\mathrm{P}$ value & $<0.001$ & $<0.001$ & 0.01 & 0.01 & 0.031 & 0.041 & $<0.001$ & 0.044 & 0.036 & $<0.001$ & 0.01 & 0.05 \\
\hline $\mathrm{LSD}_{0.05}$ & 0.11 & 0.04 & 0.09 & 0.71 & 0.79 & 0.52 & 2.66 & 1.02 & 1.80 & 0.60 & 1.24 & 0.69 \\
\hline \multicolumn{13}{|c|}{$\mathrm{TM} \times \mathrm{FC}$ interaction } \\
\hline $\mathrm{P}$ value & 0.351 & 0.065 & 0.074 & 0.159 & 0.729 & 0.451 & 0.153 & 0.762 & 0.873 & 0.581 & 0.282 & 0.138 \\
\hline $\mathrm{LSD}_{0.05}$ & ns & ns & ns & ns & ns & ns & ns & ns & ns & ns & ns & ns \\
\hline
\end{tabular}

$\mathrm{DAE}=$ days after emergence, $\mathrm{NT}=$ no-tillage, $\mathrm{CT}=$ conventional tillage, $+\mathrm{CR}=$ retention of crop residue, $-\mathrm{CR}=$ removal of crop residues, $\mathrm{NT}+\mathrm{CR}=$ notill with crop residue retention, $\mathrm{CT}-\mathrm{CR}=$ conventional tillage with no crop residue retention, $\mathrm{LSD}=$ least significant difference, ns= not significant. The biomass at 120 DAE had no cobs.

Application of PK and NPK+ZnBMgCaS treatments resulted in the lowest and highest biomass yields, respectively, at 30,60,90 and $120 \mathrm{DAE}$ across all the sites (Table 4). At $30 \mathrm{DAE}, \mathrm{NPK}+\mathrm{ZnBMgCaS}$ treatment resulted in significantly higher biomass than all other treatments in Alupe, all other treatments except NPK treatment in Embu and NP and NPK in Kirinyaga (Table 4). At 60 DAE, biomass produced from $\mathrm{NPK}+\mathrm{ZnBMgCaS}$ combination was significantly higher than NP and NPK treatments in Alupe and Embu. This trend was also observed in Kirinyaga but was only different from NPK treatment. At 90 DAE, NPK $+\mathrm{ZnBMgCaS}$ treatment yielded higher biomass than all other treatments except NPK treatment in Alupe. In Embu, $\mathrm{NPK}+\mathrm{ZnBMgCaS}$ was only different from PK treatment while in Kirinyaga it was different from
NK and PK treatment only (Table 4). At 120 DAE, $\mathrm{NPK}+\mathrm{ZnBMgCaS}$ treatment yielded higher biomass than all other treatments in Alupe, PK treatment in Embu, and NK and PK treatments in Kirinyaga. At all three sites, the interaction between tillage method and fertilizer combination was not significant.

\section{Effect of Tillage Method on Soil Moisture Conservation}

At 30, 60 and 90 DAE, tillage method had significant $(\mathrm{P}<0.05)$ effect on soil water retention at Embu and Kirinyaga sites (Table 5). No-till with crop residue retention had significantly higher soil moisture retention than conventional tillage with no crop residue retention at 30, 60 and 90 DAE in Kirinyaga and Embu sites (Table 5). 
Table 5. Effect of tillage method and crop residue management on soil moisture retention percentage at Embu and Kirinyaga trial sites during 2014 long rains season

\begin{tabular}{|c|c|c|c|c|c|c|}
\hline \multirow{2}{*}{ Treatment } & \multicolumn{2}{|c|}{$30 \mathrm{DAE}$} & \multicolumn{2}{|c|}{$60 \mathrm{DAE}$} & \multicolumn{2}{|c|}{$90 \mathrm{DAE}$} \\
\hline & Embu & Kirinyaga & Embu & Kirinyaga & Embu & Kirinyaga \\
\hline \multicolumn{7}{|c|}{ Tillage method (TM) } \\
\hline $\mathrm{NT}+\mathrm{CR}$ & 35.58 & 35.04 & 27.31 & 24.77 & 23.76 & 21.59 \\
\hline CT-CR & 30.84 & 33.10 & 26.18 & 24.25 & 19.49 & 18.04 \\
\hline $\mathrm{P}$ value & 0.009 & 0.011 & 0.010 & 0.014 & 0.005 & 0.008 \\
\hline $\mathrm{LSD}_{0.05}$ & 2.00 & 0.34 & 0.20 & 0.32 & 2.01 & 1.56 \\
\hline
\end{tabular}

$\mathrm{NT}=$ no-tillage, $\mathrm{CT}=$ conventional tillage, $+\mathrm{CR}=$ retention of crop residue, $-\mathrm{CR}=$ removal of crop residues, $\mathrm{NT}+\mathrm{CR}=$ no-till with crop residue retention, $\mathrm{CT}-\mathrm{CR}=$ conventional tillage with no crop residue retention, $\mathrm{DAE}=$ days after emergence, $\mathrm{LSD}=$ least significant difference, $\mathrm{ns}=$ not significant.

Table 6. Effect of tillage method and fertilizer combination on grain yield of maize at Alupe, Embu and Kirinyaga trial sites during 2014 long rains season

\begin{tabular}{|c|c|c|c|}
\hline \multicolumn{4}{|c|}{ Grain yield in $\mathrm{t} / \mathrm{ha}$} \\
\hline Treatment & Alupe & Embu & Kirinyaga \\
\hline \multicolumn{4}{|c|}{ Tillage method (TM) } \\
\hline $\mathrm{NT}+\mathrm{CR}$ & 3.20 & 5.40 & 4.30 \\
\hline CT-CR & 3.50 & 5.00 & 4.90 \\
\hline$P$ value & 0.046 & $<0.001$ & $<0.001$ \\
\hline $\operatorname{LSD}_{0.05}$ & 0.30 & 0.30 & 0.20 \\
\hline \multicolumn{4}{|c|}{ Fertilizer combination (FC) } \\
\hline NK & 2.80 & 5.10 & 4.50 \\
\hline NP & 3.00 & 5.10 & 4.70 \\
\hline PK & 2.30 & 5.00 & 4.20 \\
\hline NPK & 4.10 & 5.20 & 4.70 \\
\hline $\mathrm{NPK}+\mathrm{ZnBMgCaS}$ & 4.50 & 5.70 & 4.80 \\
\hline $\mathrm{P}$ value & $<0.001$ & 0.038 & 0.010 \\
\hline $\operatorname{LSD}_{0.05}$ & 0.90 & 0.40 & 0.30 \\
\hline \multicolumn{4}{|c|}{$\mathrm{TM} \times \mathrm{FC}$ interaction } \\
\hline $\mathrm{P}$ value & 0.191 & 0.076 & 0.059 \\
\hline $\operatorname{LSD}_{0.05}$ & ns & ns & ns \\
\hline
\end{tabular}

$\mathrm{LSD}=$ least significant difference, $\mathrm{NT}=$ no-tillage, $\mathrm{CT}=$ conventional tillage, $+\mathrm{CR}=$ retention of crop residue, $-\mathrm{CR}=$ removal of crop residues, $\mathrm{NT}+\mathrm{CR}=$ no-till with crop residue retention, $\mathrm{CT}-\mathrm{CR}=$ conventional tillage with no crop residue retention, $\mathrm{ns}=$ not significant

Numerically, higher moisture percentages were observed at Embu than at Kirinyaga site, irrespective of the tillage method, except at 30 DAE. Pooled means across sites showed a similar trend of high moisture percentages under NT+CR systems compared to CT-CR systems at 30, 60 and 90 DAE (Figure 2).

\section{Effect of Tillage Method and Fertilizer Combination on Maize Grain Growth}

The tillage method had a significant effect on maize grain yields at Alupe $(\mathrm{P}=0.046)$, Embu $(\mathrm{P}<0.001)$, and Kirinyaga $(\mathrm{P}<0.001) \quad($ Table 6$)$. The $\mathrm{NT}+\mathrm{CR}$ system significantly $(\mathrm{P}<0.001)$ out-yielded $\mathrm{CT}-\mathrm{CR}$ system by 0.4 $\mathrm{t} \mathrm{ha}^{-1}$ maize grain at Embu (Table 6). In contrast, CT-CR system out-yielded NT+CR system by $0.3 \mathrm{t} \mathrm{ha}^{-1}$ and $0.6 \mathrm{t}$ $\mathrm{ha}^{-1}$ maize grain at Alupe and Kirinyaga, respectively. The fertilizer combinations significantly affected grain yields at all sites. The $\mathrm{NPK}+\mathrm{ZnBMgCaS}$ treatment generally had significantly higher grain yield than NK, NP, and PK across all sites and NPK treatment at Embu. The PK treatment had lower grain yield than NP treatment at Kirinyaga. At Alupe, no grain yield differences were recorded between $\mathrm{NPK}+\mathrm{ZnBMgCaS}$ and $\mathrm{NPK}$ fertilizer combinations and among NK, NP, and PK fertilizer treatments. Fertilizer combinations NK, NP, PK, and NPK were not significantly different in grain yield at Embu. At Kirinyaga site, no significant differences were recorded among NPK+ZnBMgCaS, NPK, NK and NP treatments.
Generally, yield performance response was in the order $\mathrm{NPK}+\mathrm{ZnBMgCaS}>\mathrm{NPK}>\mathrm{NP}>\mathrm{NK}>\mathrm{PK}$, across all sites (Table 6). There was no significant interaction effect observed between tillage method and fertilizer combinations on maize grain yield at all the sites

\section{Discussion}

\section{Effects of Tillage Method On Maize Growth and Grain Yield}

Maize under CT-CR recorded higher leaf area index (LAI), plant height, aboveground biomass, and crop growth rate (CGR) than under $\mathrm{NT}+\mathrm{CR}$ at Alupe and Kirinyaga. This finding confirms observations reported by Shrestha et al. (2013) and Memon et al. (2012). However, at Embu, taller plants were recorded under NT+CR than under CT-CR system. The CGR was observed to increase from emergence towards 90 DAE during this trial. A similar phenomenon was reported by Karimi and Siddique (1991) on maize where CGR was low at the beginning of the season and progressively increased to a maximum value at around 125 growing degree day (GDD) from sowing. Higher maize CGR was recorded under CT-CR than under NT+CR systems. This observation confirms the findings of Halvorson et al. (2006) that showed slower early growth rates under conservation agriculture than under conventional tillage. This may be attributed to the compacted soils especially under high clay content that 
reduces water infiltration and general root growth under no-till. In addition, the use of herbicides has been shown to have some growth retarding effect- scorching of young plants and lower leaves- in the early stages of maize growth (Thomas, 1986). Higher maize grain yields were recorded under CT-CR than under NT+CR at Alupe and Kirinyaga. This observation is similar to Hoffmann and Kismányoky (2001) who reported consistently higher maize yield under conventional tillage than under no-till and reduced till plots. Previous researchers have also shown a reduction in maize grain yields with reduction in tillage (Filipović et al., 2004; Kihara et al., 2012). The better performance of CTCR system observed was maybe a result of loose soils under conventional tillage practice which allowed faster maize root penetration and development, water infiltration and stronger anchorage (Sharma et al., 2010). Also, removal of crop residue under CT-CR system may have allowed light showers of rainfall to reach the soil which would otherwise be blocked by crop residue cover under conservation agriculture (Wang et al., 2012). Low yields under conservation agriculture at Alupe and Kirinyaga may also be attributed to early slower growth rate than under conventional tillage (Halvorson et al., 2006), although Beyaert et al. (2002) observed that early slow maize growth in zero tillage had a non-significant effect on ultimate grain yield. However, NT+CR system out-yielded CT-CR system at Embu site. This is similar to the finding by Sommer et al. (2014) who reported increased maize yields under conservation agriculture compared to conventional tillage systems. Also, Otieno et al (2020) reported consistently higher dry bean grain yields under conservation agriculture (combination of no-tillage and crop residue retention) than under conventional tillage (combination of conventional tillage and removal of crop residue) across all trial sites in Kenya. This may have been due to crop residue retention which is known to lower evaporation rates resulting in higher water retention than under CT-CR system. This is evidenced by the consistently higher soil water contents at Embu and Kirinyaga obtained in this trial. The stored water may have been made available for use by maize during low rainfall periods in the region. The stored water could have also increased nutrient utilization hence better performance, especially during low rainfall periods in Embu. The effect of the stored water is expected to be better in Embu than in Kirinyaga due to the high moisture retention percentages recorded throughout. This could be explained by the high activity of termites observed in Alupe and Kirinya leaving soil surface less covered than at Embu. The termite activity was among the observations made during the season; however, no quantitative data was collected.

\section{Effect of Different Fertilizer Combinations on Maize Growth and Grain Yield}

Omission of nitrogen (PK treatment) resulted in shorter plants and reduced leaf area indices, biomass production, CGR and grain yields. From the nutrient responses, N was the most limiting nutrient followed by $\mathrm{P}$ and $\mathrm{K}$. These findings are in line with those from a trial carried out in western Kenya by Ngome et al. (2013) and Otieno (2018a) who reported high maize yields due to $\mathrm{N}$ fertilizer application. The best performance in plant attributes was recorded under $\mathrm{NPK}+\mathrm{ZnBMgCaS}$ followed by $\mathrm{NPK}, \mathrm{NP}$, and NK combination. Such great influence of $\mathrm{N}$ is due to its pivotal roles in many physiological and biochemical processes such as protein formation and chlorophyll synthesis.

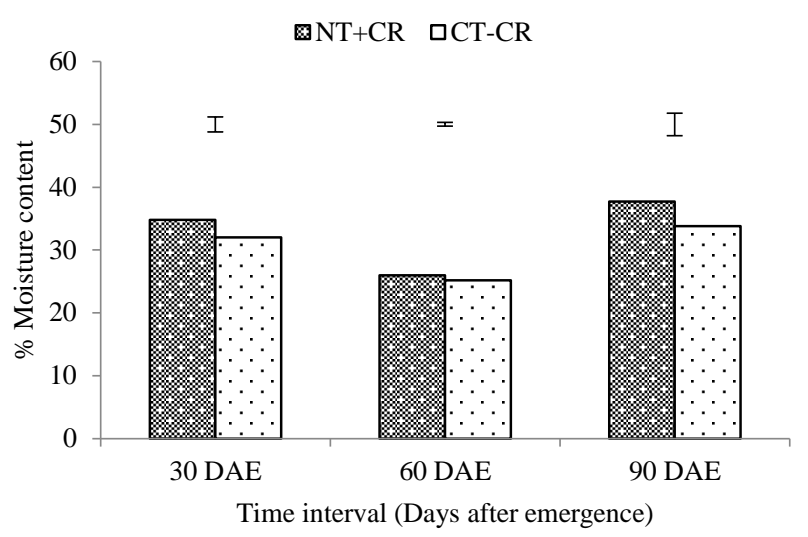

Figure 2. Pooled effect of tillage method and crop residue management on soil moisture retention levels during 2014 long rains season.

The bars represent the LSD bars. NT= no-tillage, $\mathrm{CT}=$ conventional tillage, $+\mathrm{CR}=$ retention of crop residue, $-\mathrm{CR}=$ removal of crop residues, $\mathrm{NT}+\mathrm{CR}=$ no-till with crop residue retention, $\mathrm{CT}-\mathrm{CR}=$ conventional tillage with no crop residue retention

Combined application of a wide range of nutrients (treatments $\mathrm{NPK}+\mathrm{ZnBMgCaS}$ and NPK) resulted in better crop performance than a narrow range of nutrients (NP, $\mathrm{NK}$, and PK) in terms of biomass production, CGR, LAI, height, and grain yield. These results are in agreement with previous findings by Otieno et al. (2018a and 2019a) who reported that combined application of NPK with micronutrients resulted in higher maize biomass and grain yield than NPK, NP, NK and PK combinations. Micronutrients play important roles in growth and have been reported to increase maize dry biomass and grain yield; the impact of $\mathrm{Cu}, \mathrm{S}$ and $\mathrm{Mg}$ by Khatri-Chhetri and Schulte (1985) and Ca and B by Kanwal et al. (2008). The current findings indicate that other than $\mathrm{N}, \mathrm{P}$ and $\mathrm{K}$, secondary nutrients $(\mathrm{Mg}, \mathrm{Ca}$ and $\mathrm{S}$ ) and micronutrients $(\mathrm{Zn}$ and B) may be limiting in farmers' fields and need to be ameliorated. When nutrients are applied together, they work synergistically to ameliorate deficiencies and inefficiencies with which essential nutrients are used for improved growth and yield (Jakobsen, 2009). This may explain why maize under $\mathrm{NPK}+\mathrm{ZnBMgCaS}$ out-yielded most other treatments while NPK out-yielded NK, NP and PK treatments in most cases. Phosphorus plays an important role in energy storage and transfers in crop plants (IPNI, 1999; Malhotra et al., 2018). Together, P, K, and Zn may have increased tolerance of maize to environmental stresses like drought and disease attacks through enhanced development of roots and stalks (Jin et al., 2006; Alloway, 2008; Fageria and Baligar, 2009). Calcium and magnesium are important in enzyme activation, nutrient uptake and ion balance (Fageria and Gheyi, 1999), carbohydrate translocation, stiffness of maize straw and grain and seed formation (Fageria and Baligar, 2009). Boron, on the other hand, may have helped in pollen germination and tube formation and seed formation resulting in increased number of seeds per cob and maize grain yield (Sherchan et al., 2004; Kaur and Nelson, 2015). 


\section{Conclusion and Recommendation}

Maize performance in terms of leaf area index, plant height, aboveground biomass production at 30,60 and 90 days after emergence and crop growth rate was higher under conventional tillage with no crop residue retention than under no-till with crop residue retention at Alupe and Kirinyaga trial sites. Higher moisture retention was observed under no-till with crop residue retention than under conventional tillage with no crop residue. Fertilizer application is important in improving maize performance across all sites. A wide range of nutrients improves growth and yield parameters better than narrow combinations. The $\mathrm{NPK}+\mathrm{ZnBMgCaS}$ combination recorded higher grain yield than most of the other nutrient combinations across all sites while the PK treatment had the lowest maize growth and yield in all trial locations. This trial should be carried out in multiple seasons and sites so as to accurately determine the response of maize to tillage and fertilizer management. Also, the effects of individual micronutrients need to be investigated separately.

\section{Acknowledgments}

The authors appreciate the financial support offered by the International Plant Nutrition Institute (IPNI) and International Maize and Wheat Improvement Center (CIMMYT) and the technical and professional guidance offered by the College of Agriculture and Veterinary Sciences, University of Nairobi.

\section{Conflicts of Interest}

The authors declare no conflict of interest

\section{References}

Alloway BJ .2008. Zinc in soils and crop nutrition. Second edition, published by International Zinc Association and International Fertilizer Industry Association, Brussels, Belgium and Paris, France. ISBN 978-90-8133-310-8.

Beyaert RP, Schott JW, White PH. 2002. Tillage effects on corn production in a coarse-textured soil in Southern Ontario. Agronomy, 94: 767-774.

Blanco FF, Folegatti MV. 2003. A new method for estimating the leaf area index of cucumber and tomato plants. Horticultura Brasileira, Brasília Journal, 21(4): 666-669.

Ciganda V, Gitelson AA, Schepers JS. 2009. Non-destructive determination of maize leaf and canopy chlorophyll content. Journal of Plant Physiology, 166(2): 157-167.

Drechsel P, Kunze D, Vries FP De. 2001. Soil nutrient depletion and population growth in Sub-Saharan Africa: A Malthusian Nexus? Population and Environment, 22(4): 411-423.

Fageria NK, Gheyi HR. 1999. Efficient crop production. Campina Grande, Brazil: Federal University of Paraiba.

Fageria NK, Baligar VC. 2009. Response of common bean, upland rice, corn, wheat, and soybean to soil fertility of an Oxisol. Journal of Plant Nutrition, 20: 1279-1289.

Fageria NK, Baligar VC, Moreira A, Portes TA. 2010. Dry bean genotypes evaluation for growth, yield components and phosphorus use efficiency. Journal of Plant Nutrition, 33: 2167-2181.

Filipović D, Košutić S, Gospodarić Z. 2004. Influence of different soil tillage systems on fuel consumption, labour requirement and yield in maize and winter wheat production. POLJOPRIVREDA, 10(2): 17-23.
Halvorson AD, Mosier AR, Reule CA, Bousch WC. 2006. Nitrogen and tillage effects on irrigated continuous corns. Agronomy, 98: 63-71.

Hoffmann S, Kismányoky T. 2001. Soil fertility in a long term fertilizer trial with different tillage systems. Archives of Agronomy and Soil Science Journal, 46(3-4): 239-250.

Hunt R. 2003. Growth analysis, individual Plants. In: Thomas B, Murphy DJ and Murray D (Eds) Encyclopaedia of Applied Plant Science, 588-596.

IPNI.1999. International Plant Nutrition Institute, Functions of Phosphorus in Plants. Better Crops/Vol. 83 (1999, No. 1)

Jaetzold R, Schmidt H. 1983. Farm management handbook of Kenya, Vol. II/A E. West Kenya, Vol. II/B Central Kenya and Vol. II/C East Kenya. Farm management handbook of Kenya Volume II. Natural conditions and farm management information. Ministry of Agriculture, Nairobi, Kenya.

Jakobsen ST. 2009. Interaction between plant nutrients: Theory and analytical procedures. Acta Agriculturae Scandinavica Section B, Plant and Soil Sciences Journal, 42(4): 208-212.

Jin J, Wang G, Liu X, Pan X, Herbert JS, Tang C. 2006. Interaction between phosphorus nutrition and drought on grain yield, and assimilation of phosphorus and nitrogen in two Soybean cultivars differing in protein concentration in grains. Journal of Plant Nutrition, 29: 1433-1449.

Kanwal S, Rahmatullah, Aziz T, Maqsood MA, Abbas N. 2008. Critical ratio of calcium and boron in maize shoot for optimum growth. Journal of Plant Nutrition, 31: 1535-1542.

Karimi MM, Siddique KHM. 1991. Crop growth and relative growth rate of old and modern wheat cultivars. Australian Journal of Agricultural Resources, 42: 13-20.

Kaur G, Nelson KA. 2015. Effect of foliar boron fertilization on fine textured soils on corn yields. Agronomy, 5(1): 1-18.

Khatri-Chhetri TB, Schulte EE. 1985. Response of maize to the application of secondary and micronutrients in the soils of the Chitwan Valley, Nepal, II: Results of multilocation trials. Journal of the Institute of Agriculture and Animal Science, 6: 59-76

Kihara J, Mukalama J, Ayuke FO, Njoroge S, Waswa B, Okeyo J, Koala S, Bationo A. 2012. Crop and soil response to tillage and crop residue application in a tropical ferralsol in subhumid Western Kenya. In A. Bationo et al. (eds.), Lessons learned from Long-term soil fertility management experiments in Africa, (C) Springer Science+Business Media Dordrecht 2012.

Klute A. 1986. Water Retention- Laboratory Methods. In: Methods of Soil Analysis, 528 Part 1. Physical and Mineralogical Methods. 2nd ed. Agronomy Monographs, No. 529 9. Klute, A. (Eds.), American Society of Agronomy and Soil Science Society of 530 America, Madison, Wisconsin, pp. 635-662.

Malhotra H, Sharma S, Pandey R. 2018. Phosphorus nutrition: plant growth in response to deficiency and excess. In Plant Nutrients and Abiotic Stress Tolerance (pp. 171-190). Springer, Singapore.

Memon SQ, Mirjat MS, Mughal AQ, Amjad N. 2012. Effects of different tillage and fertilizer treatments on growth and yield components of maize. Pakistan Journal of Agriculture, Agricultural Engineering, Veterinary Sciences, 28(2): 160-176.

Mugwe J, Mugendi D, Kungu J, Muna MM. 2009. Maize yields response to application of organic and inorganic input under on-station and on-farm experiments in central Kenya. Experimental Agriculture, 45: 47-59.

Mwangi JN, Mugendi DN, O’Neill KM. 1998. Crop yield response to incorporation of leaf pruning in sole and alley cropping systems. East Africa Agricultural Journal, 62: 209218.

Ngome AF, Becker M, Mtei MK, Mussgnug F. 2013. Maize productivity and nutrient use efficiency in Western Kenya as affected by soil type and crop management. International Journal of Plant Production, 7(3): 517- 536. 
Okalebo JR, Othieno CO, Woomer PL, Karanja NKM, Semoko JRM, Bekunda, MA, Mugendi DN, Muasya RM, Batiano A. 2007. In Batiano A (Eds.) Advances in integrated soil fertility management in Sub-Sahara Africa: Challenges and Opportunities, 45-62.

Omoyo NN, Wakhungu J, Oteng'i S. 2015. Effects of climate variability on maize yield in the arid and semi-arid lands of lower eastern Kenya. Agriculture and Food Security, 4(1): 8.

Otieno HMO, Chemining'wa GN, Zingore S, Gachene CK. 2020. Tillage Method and Residual N, P, K, Zn, B, Mg, Ca, and S Nutrients Effect on Growth and Yield of Dry Bean Grown after the Harvest of Maize. Turkish Journal of AgricultureFood Science and Technology, 8(1), pp.18-26.

Otieno HMO, Chemining'wa GN, Gachene CK, Zingore S. 2019. Economics of maize and bean production: Why Farmers need to shift to conservation agriculture for sustainable production. Turkish Journal of Agriculture-Food Science and Technology, 7(10): 1548-1553.

Otieno HMO, Chemining'wa GN, Zingore S, Gachene CK. 2018a. Effects of inorganic fertilizer application on grain yield, nutrient-use efficiency and economic returns of maize in Western Kenya. Journal of Advanced Studies in Agricultural, Biological and Environmental Sciences, 5(4): 11-22.

Otieno HMO, Chemining'wa GN, Zingore S, Gachene CK. $2018 \mathrm{~b}$. Effects of inorganic fertilizer application on grain yield, nutrient-use efficiency and economic returns of maize in Western Kenya. Journal of Advanced Studies in Agricultural, Biological and Environmental Sciences, 5(4): 11-22.

Otieno HMO. 2019a. Growth and yield response of maize (Zea mays L.) to a wide range of nutrients on ferralsols of western Kenya. World Scientific News, 129: 96-106.

Otieno HMO. 2019b. Pesticide training tool: A simplified guide for Agricultural Extension Officers and Farmers. Asian Journal of Research in Crop Science, 1-5.

Pierce LL, Running SW .1988. Rapid estimation of coniferous forest leaf area using a porta integrating radiometer. Ecology, 69: 1762-1767.

Reliefweb Report .2019. Kenya: Drought - 2014-2019. Available at https://reliefweb.int/disaster/dr-2014-000131-ken

Sanchez PA, Shepherd KD, Soule MJ, Place FM, Buresh RJ. Izac AMN, Uzo MA, Kwesiga FR, Ndiritu, CG, Woomer PL. 1997. Soil fertility replenishment in Africa: an investment in natural resource capital. In: Replenishing soil fertility in Africa; RJ Buresh, PA Sanchez and F Calhoun (Ed.). WI. Soil Sci. Soc. Am. Madison. Special Publication, 51: 1-46.
Sharma AR, Singh R, Dhyani SK, Dube RK .2010. Moisture conservation and nitrogen recycling through legume mulching in rain-fed maize (Zea mays)-wheat (Triticum aestivum) cropping system, Nutrient Cycling in Agroecosystems, 87: 187-197.

Sherchan DP, Upreti R, Maskey SL. 2004. Effect of micronutrients on production of maize in the acid soils of Chitwan Valley. pp. 169 - 180. In: Proceedings of an International Workshop. Micronutrient in South and South East Asia (September 8- 11, 2004). Kathmandu, Nepal.

Shrestha J, Bk SB, Srivastav SB, Gurung SB, Ferrara GO. 2013. Effect of conservation agriculture on growth and productivity of maize in Terai Region of Nepal. Merit Research Journal of Agricultural Science and Soil Sciences, 1(5): 66-77.

Sommer R, Piggin C, Feindel D, Ansar M, Delden L Van, Shimonaka K, Ryan J. 2014. Effects of zero tillage and residue retention on soil quality in the Mediterranean region of Northern Syria. Open Journal of Soil Science, 4: 109-125.

Szulc P, Waligóra H and Skrzypczak W. 2008. Better effectiveness of maize fertilization with nitrogen through additional application of magnesium and sulphur. Nauka Przyroda Technologie, 2(3): 19.

Thomas PEL. 1986. Evaluation of the effects of scorching caused by the directed application of a paraquat-containing herbicide mixture to the base of maize plants at various ages, South African Journal of Plant and Soil, 3:1, 18-20.

Vanlauwe B, Bationo A, Chianu J, Giller KE, Merckx R, Mokwunye U, Ohiokpehai O, Pypers, P, Tabo R, Shepherd K, Smaling EMA, Woomer PL. 2010. Integrated soil fertility management: operational definition and consequences for implementation and dissemination. Outlook Agriculture, 39: $17-24$.

Wang XB, Wu HJ, Dai K, Zhang KDC, Feng ZH, Zhao Wu XP, Jin K, Cai DX, Oenema O, Hoogmoed WB. 2012. Tillage and crop residue effects on rain-fed wheat and maize production in northern China, Field Crops Research, 132: 106-116.

Yerokun OA, Chirwa M. 2014. Soil and foliar application of zinc to maize and wheat grown on a Zambian Alfisol. African Journal of Agricultural Research, 9(11): 963-970. 